\title{
Growth, Quality, and Foliar Iron Concentration of Kentucky Bluegrass Treated with Chelated Iron Sources
}

\author{
R.J. Cooper'and L.A. Spokas ${ }^{2}$ \\ Department of Plant and Soil Sciences, University of Massachusetts, Amherst, MA 01003 \\ Additional index words. fertilization, micronutrients, Poa pratensis, turfgrass
}

\begin{abstract}
Supplemental Fe fertilization to improve turfgrass quality has become an increasingly common practice on many turfgrass areas. Field studies were conducted to evaluate the nutrient uptake, growth, and quality of Kentucky bluegrass (Pea pratensis $\mathbf{L}$.) treated with chelated Fe sources. Iron sources were evaluated over 2 years at $1.5,3.0$, and $6.0 \mathrm{~kg} \mathrm{Fe} / \mathrm{ha}$ applied in May, July, and September of each year. Turf treated with an iron orthophosphate citrate source (Fe-PC) exhibited more foliar growth than nontreated turf on seven of 11 sampling dates during the study. Iron citrate sources $[\mathrm{Fe}-\mathrm{C}(\mathrm{EI})$ and $\mathrm{Fe}-\mathrm{C}(\mathrm{T})]$ and Fe-DTPA applications resulted in similar growth rates, never stimulating growth more than the Fe-PC source and rarely increasing growth compared with nontreated turf. Increasing the Fe rate within source did not typically increase growth. Iron-treated turf exhibited quality superior to nontreated turf throughout the study with all sources performing comparably. Increasing Fe rate did not result in a corresponding increase in quality, due to greater phytotoxicity at higher rates. Although several sources produced notable phytotoxicity at $6.0 \mathrm{~kg}$ Fe/ha, repeated application did not decrease turfgrass density. Iron tissue content increased linearly with rate on four of five sampling dates during the study however, no source resulted in tissue Fe content significantly higher than other sources. Application of sources containing supplemental $\mathbf{P}$ and/or $\mathbf{K}$ did not increase tissue $P$ or $K$ content. Chemical names used: iron citrate (Fe-C); iron diethylenetriamine pentaacetate (FeDTPA); iron orthophosphate citrate (Fe-PC).
\end{abstract}

Color is one of the most important characteristics that contribute to visual turfgrass quality. Turfgrass managers often rely primarily upon $\mathrm{N}$ to develop dark green turfgrass. Excessive $\mathrm{N}$ fertility, however, increases mowing costs and susceptibility to certain environmental stresses and diseases and may adversely affect rooting (Turgeon, 1991). A well-planned Fe fertility program can improve color while reducing the potential negative effects associated with excessive $\mathrm{N}$ application (Yust et al., 1984).

The usefulness of Fe for improving turfgrass color has been well established (Carrow et al., 1988; Deal and Engle, 1965; Minner and Butler, 1984). In addition to improving color, Fe fertilization has been shown to enhance creeping bentgrass (Agrostis palustris Huds.) recovery from winter desiccation injury (Snyder and Schmidt, 1974). Also, bermudagrass [Cynodon dactylon (L.) Pers. $\times$ C. transvaalensis Burtt-Davy] vigor during exposure to chilling temperatures (White and Schmidt, 1988) and postemergence herbicide tolerance (Johnson et al., 1990) have been enhanced by foliar Fe application.

While the benefits to turfgrass from Fe fertilization are generally accepted, little is known concerning the relative merits of varying Fe sources. Supplemental Fe fertilization of turf has historically consisted primarily of foliar application of sources containing either iron sulfate or Fe-DTPA. Within the past few years, however, Fe-containing products for turf that use citratebased chelating agents and contain essential elements including $\mathrm{Mn}, \mathrm{P}, \mathrm{K}$, and $\mathrm{S}$ have become available.

The purpose of this work was to evaluate four commonly

\footnotetext{
Received for publication 7 Sept. 1990. Contribution from the Massachusetts Agr. Expt. Sta., Amherst. Journal Article no. 2992. This work was supported in part by Hatch Act funds (Project 635) allocated to the Massachusetts Agr. Expt. Sta. We thank W.A. Torello, Dept. of Plant and Soil Sciences, for his assistance during the initial stages of this research. The cost of polishing this paper was defrayed in part by the payment of page charges. Under postal regulations, this paper therefore must be hereby marked advertisement solely to indicate this fact.
}

'Associate Professor.

${ }^{2}$ Research Technician. used sources of chelated Fe having varied chelating agents and nutrient composition. Characteristics studied included turfgrass growth and quality in response to Fe source and application rate, $\mathrm{Fe}$ source effects on Fe uptake efficiency, and the influence of supplemental $\mathrm{P}$ and $\mathrm{K}$ on tissue content of those elements.

\section{Materials and Methods}

Field studies were conducted on a 3-year-old blend of 'Touchdown' and 'Baron' Kentucky bluegrass growing on a Hadley silt loam soil (coarse, silty, mixed, nonacid, mesic Typic Udifluvent) at the Univ. of Massachusetts Turfgrass Research Center in South Deerfield. A composite soil sample obtained from the test area before treatment was analyzed by the Massachusetts Soil Testing Laboratory using the Morgan Soil Testing System (Lunt et al., 1950). The extracting solution was a $10 \%$ solution of sodium acetate $(0.73 \mathrm{~N})$ in $3 \%$ acetic acid $(0.52 \mathrm{~N})$. Analysis yielded the following results: $\mathrm{pH} 6.2,25 \mathrm{mg} \mathrm{P} / \mathrm{kg}$ (high), 140 $\mathrm{mg} \mathrm{K} / \mathrm{kg}$ (high), and $2.2 \mathrm{mg} \mathrm{Fe} / \mathrm{kg}$. Chelated Fe sources (Table 1) were applied at rates of $1.5,3.0$, or $6.0 \mathrm{~kg} \mathrm{Fe} / \mathrm{ha}$ on $20 \mathrm{May}$, 15 July, and 10 Sept. 1986 and on 13 May, 8 July, and 16 Sept. 1987. Treatments were applied to $0.91 \times 2.74-\mathrm{m}$ plots using a $\mathrm{CO}_{2}$-powered backpack sprayer at $207 \mathrm{kPa}$ pressure delivering 1300 liters $\cdot \mathrm{ha}^{-1}$ A factorial arrangement of Fe sources and rates was used in a randomized complete-block design with three replications. Turf was mowed to $5.0 \mathrm{~cm}$ twice per week throughout the study, with irrigation applied as needed to prevent drought stress. Supplemental fertilization was minimal, with urea (45 N-OP-OK) applied at $25 \mathrm{~kg} \mathrm{~N} / \mathrm{ha}$ in late May each year. Iron sources contained no N.

Growth rate. Clippings were harvested 2 weeks (+2 days) and 7 weeks ( \pm 6 days) after treatment (WAT) during both years of the study to assess Fe effects on plant vigor. The turf was mowed to a height of $5.0 \mathrm{~cm}$, then allowed to grow for 3 days before being harvested. Clippings were collected by making one pass lengthwise through each plot with a reel mower $45.0 \mathrm{~cm}$ wide at $5.0-\mathrm{cm}$ height. The total area harvested from each plot was 0.9 $\mathrm{m}^{2}$. Clippings were oven-dried for 2 days at $72 \mathrm{C}$ and weighed. 
Table 1. Chelated Fe sources evaluated in the experiment.

\begin{tabular}{|c|c|c|c|c|c|c|c|}
\hline Fe source & Chelate type & Abbrev. & $\mathrm{Fe}$ & $\mathbf{K}$ & $\mathrm{P}$ & $\mathrm{Mg}$ & $S$ \\
\hline Agri-plex 4X & $\begin{array}{l}\text { Fe-orthophosphate } \\
\text { citrate }\end{array}$ & $\mathrm{Fe}-\mathrm{PC}$ & 50 & 33.2 & $\begin{array}{r}\mathrm{g} \cdot \mathrm{kg}^{-1} \\
17.6\end{array}$ & 30 & 40 \\
\hline Extra-Iron & Fe-citrate & $\mathrm{Fe}-\mathrm{C}(\mathrm{EI})$ & 40 & --- &.-- & -- & 50 \\
\hline Trugreen & Fe-citrate & $\mathrm{Fe}-\mathrm{C}(\mathrm{T})$ & 12.5 & 16.6 & -- & 10 & 20 \\
\hline Sequestrene 330 & Fe-DTPA & Fe-DTPA & 100 & -- & -- & ..- & --- \\
\hline
\end{tabular}

${ }^{\mathrm{z}}$ Mention of a brand or trade name does not imply endorsement by the Univ. of Massachusetts. AgriPlex 4X (RGB Laboratories, Kansas City, Mo.); Extra-Iron and Trugreen (W.A. Cleary Chemical, Somerset, N.J.); Sequestrene 330 (Ciba-Geigy, Greensboro, N.C.).

Turfgrass quality. Turfgrass quality is a composite of several characteristics including uniformity, density, texture, and color. In addition, any phytotoxicity associated with the Fe sources was considered in quality ratings. Visual quality was rated regularly throughout the growing season in both years of the study, using a scale where 1 = brown, low-quality turf; 5 = acceptable; and 9 = dark green, high-quality turf.

Mineral nutrient analysis. To ascertain if Fe uptake efficiency varied with source, and to determine if sources containing supplemental $\mathrm{P}$ and/or $\mathrm{K}$ resulted in elevated tissue levels of those elements, leaf tissue was analyzed periodically during the study. Samples were harvested as described for growth rate analysis, then dried and stored until analysis. Tissue was dry-ashed with nutrient analysis performed according to the methods of Greweling (1976). Phosphorous was determined as molybdovanadophosphoric acid using a Perkin-Elmer Model 124D double beam spectrophotometer (Perkin-Elmer Corp., Norwalk, Conn.). Iron and K content were determined using an Instrumentation Laboratories atomic absorption spectrophotometer Model 551 (Instrumentation Laboratory, Wilmington, Mass.) using flame photometry for $\mathrm{Fe}$ and atomic absorption spectrophotometry for K.

Statistical analysis. All data were subjected to an analysis of variance (ANOVA) using the Statistical Analysis System (SAS Institute, Inc., 1982) with treatment sum of squares partitioned into source, rate, and source $\times$ rate effects. Duncan's multiple range test was employed for mean separation if the ANOVA F test indicated that Fe source effects were significant. Significant Fe rate effects were evaluated using stepwise polynomial regression (SAS Institute, Inc., 1982).

\section{Results and Discussion}

Growth rate. When rated 14 to 16 DAT during $1986, \mathrm{Fe}-\mathrm{PC}$ application resulted in more growth than Fe-C(EI), Fe-DTPA, and nontreated turf (Table 2). Fe-PC also provided growth superior to Fe-C(T) when evaluated on 24 Sept. and 29 Oct. 1986. While Fe-PC application stimulated significantly more growth than no treatment on all dates when significant differences among sources existed, the effect of $\mathrm{Fe}-\mathrm{C}$ sources was less conclusive.

Increased growth in response to Fe application during 1986 differs from results of Deal and Engle (1965) and Yust et al. (1984) who found that Fe application had no effect on Kentucky bluegrass shoot growth. Their studies, however, evaluated only $\mathrm{FeSO}_{4}$ and/or Fe-DTPA application, not Fe-PC or Fe-C sources. In addition, Yust et al. (1984) evaluated Fe applications combined with $\mathrm{N}$ and speculated that supplemental $\mathrm{N}$ fertility may have obscured any $\mathrm{Fe}$ effects on growth rate. In our study, except for 22 July 1987, Fe-DTPA failed to significantly stimulate turf growth relative to nontreated turf, thus confirming the findings of Deal and Engle (1965) and Yust et al. (1984). Snyder and Schmidt (1974) and Schmidt and Snyder (1984), work-
Table 2. Foliar growth (dry-weight basis) of Kentucky bluegrass in response to applications of chelated $\mathrm{Fe}$.

\begin{tabular}{|c|c|c|c|c|c|c|}
\hline \multirow[b]{2}{*}{ Source } & \multicolumn{6}{|c|}{ Date (days after treatment), $1986^{2}$} \\
\hline & $\begin{array}{c}1 \text { July } \\
(42)\end{array}$ & $\begin{array}{l}31 \text { July } \\
\text { (16) }\end{array}$ & $\begin{array}{l}26 \text { Aug. } \\
\text { (42) }\end{array}$ & $\begin{array}{l}24 \text { Sept. } \\
\text { (14) }\end{array}$ & $\begin{array}{l}29 \text { Oct. } \\
\text { (49) }\end{array}$ & \\
\hline & \multicolumn{6}{|c|}{$g \cdot m^{-2}$} \\
\hline $\mathrm{Fe}-\mathrm{PC}$ & $2.4^{y}$ & $3.6 \mathrm{a}^{\mathrm{x}}$ & 2.2 & $5.2 \mathrm{a}$ & $2.7 \mathrm{a}$ & \\
\hline $\mathrm{Fe}-\mathrm{C}(\mathrm{EI})$ & 2.5 & $2.2 \mathrm{~b}$ & 2.1 & $4.0 \mathrm{~b}$ & $1.7 \mathrm{~b}$ & \\
\hline $\mathrm{Fe}-\mathrm{C}(\mathrm{T})^{\prime}$ & 2.5 & $3.2 \mathrm{a}$ & 2.1 & $4.1 \mathrm{~b}$ & $1.7 \mathrm{~b}$ & \\
\hline Fe-DTPA & 1.8 & $2.2 \mathrm{~b}$ & 1.5 & $3.3 \mathrm{bc}$ & $1.9 \mathrm{~b}$ & \\
\hline Nontreated & 2.2 & $1.9 \mathrm{~b}$ & 1.9 & $2.5 \mathrm{c}$ & $1.4 \mathrm{~b}$ & \\
\hline \multirow[t]{4}{*}{ F test } & NS & $* *$ & NS & $* *$ & $* *$ & \\
\hline & \multicolumn{6}{|c|}{1987} \\
\hline & $\begin{array}{c}27 \text { May } \\
(14)\end{array}$ & $\begin{array}{l}24 \text { June } \\
(42)\end{array}$ & $\begin{array}{c}22 \text { July } \\
\text { (14) }\end{array}$ & $\begin{array}{c}31 \text { Aug. } \\
(54)\end{array}$ & $\begin{array}{c}2 \text { Oct. } \\
(16)\end{array}$ & $\begin{array}{l}30 \text { Oct. } \\
(44)\end{array}$ \\
\hline & \multicolumn{6}{|c|}{$g \cdot m^{-2}$} \\
\hline $\mathrm{Fe}-\mathrm{PC}$ & $3.0 \mathrm{a}$ & 6.0 & $5.2 \mathrm{a}^{5}$ & $7.7 \mathrm{a}$ & 9.6 & $1.8 \mathrm{a}$ \\
\hline $\mathrm{Fe}-\mathrm{C}(\mathrm{EI})$ & $1.8 \mathrm{~b}$ & 4.8 & $4.6 \mathrm{abc}$ & $4.8 \mathrm{~b}$ & 8.2 & $0.9 \mathrm{~b}$ \\
\hline $\mathrm{Fe}-\mathrm{C}(\mathrm{T})$ & $2.0 \mathrm{~b}$ & 5.7 & $3.7 \mathrm{bc}$ & $5.5 \mathrm{~b}$ & 8.6 & $1.1 \mathrm{~b}$ \\
\hline Fe-DTPA & $1.9 \mathrm{~b}$ & 4.7 & $4.9 \mathrm{ab}$ & $6.5 \mathrm{ab}$ & 8.5 & $1.0 \mathrm{~b}$ \\
\hline Nontreated & $1.5 \mathrm{~b}$ & 4.6 & $3.5 \mathrm{c}$ & $5.8 \mathrm{~b}$ & 8.4 & $0.8 \mathrm{~b}$ \\
\hline F test & $* *$ & NS & $* *$ & $*$ & NS & $* *$ \\
\hline
\end{tabular}

Treatments applied 20 May, 15 July, 10 Sept. 1986, and 13 May, 8 July, 16 Sept. 1987.

yData are the mean of three replicates, averaged across all rates.

'Mean separation within columns by Duncan's new multiple range test, $P=0.05$.

NS,*,**Nonsignificant or significant at $P=0.05$ or 0.01 , respectively.

ing with field- and growth chamber-grown creeping bentgrass, respectively, reported that Fe-DTPA and iron sulfate application rate influenced turf growth rate. Their work, however, indicated that Fe-DTPA application caused top growth to increase only during cool weather and actually depressed top growth as temperatures rose. Glinski et al. (1988) evaluated $\mathrm{FeSO}_{4}, \mathrm{Fe}-\mathrm{PC}$, and Fe-DTPA applications to creeping bentgrass and reported a $10 \%$ decline in shoot growth from monthly Fe-DTPA applications at $0.12 \mathrm{~kg} \mathrm{Fe} / \mathrm{ha}$. Iron application in our study never significantly decreased growth compared with nontreated turf, regardless of prevailing temperatures.

During 1987, Fe-PC-treated turf grew more than nontreated turf on four of six sampling dates (Table 2). Fe-PC treatment resulted in mean clipping yields $58 \%$ higher than obtained for nontreated turf while Fe-C sources and Fe-DTPA led to growth similar to that of nontreated turf.

In addition to growth effects attributable directly to the Fe sources, clipping yields averaged for all sources increased with increasing Fe rate on 24 Sept. $1986(\mathrm{Y}=0.84 \mathrm{X}+3.4)$ and 22 July $1987(\mathrm{Y}=0.94 \mathrm{X}+3.7)$. In general, however, increasing Fe rate did not affect growth. 
Turfgrass quality. During 1986, Fe-DTPA was the only Fe source that provided quality superior to nontreated turf during every rating period where significant source effects occurred (Table 3). Application of $\mathrm{Fe}-\mathrm{PC}$ and $\mathrm{Fe}-\mathrm{C}$ sources resulted in quality superior to nontreated turf during the week following application on two of three rating dates. When evaluated 30 DAT or later during 1986, all Fe sources performed comparably, each increasing quality significantly compared with nontreated turf during two of three rating periods. Throughout the year, turf quality benefited from Fe application with no source clearly superior.

Trends in quality response to Fe sources during 1987 were similar to those noted during 1986. Fe-DTPA-treated turf exhibited quality superior to nontreated turf for every rating during 1987. Application of Fe-PC or Fe-C sources improved quality compared with nontreated turf during at least four of six rating periods during the season. While turf quality was clearly improved by Fe application, all Fe sources performed similarly.

Iron application rate did not significantly influence turfgrass quality during either year of the study. Even for quality ratings taken as late as $42 \mathrm{DAT}$, higher Fe rates did not provide residual quality superior to the lowest rate. Carrow et al. (1988), working with common centipedegrass [Eremochloa ophiuroides (Munro.) Hack.],reported that when visual quality ratings were taken $\geq 2$ weeks after treatment (with soluble, nonchelated Fe sources), the highest Fe rate always gave the best ratings. The lack of residual rate effects on quality observed in our study maybe related to the tendency of chelated Fe sources to provide color enhancement for a longer period than nonchelated Fe sources.

Throughout the study, sources differed primarily in regard to the degree of phytotoxicity produced rather than duration of the color response. Phytotoxicity was evident with rates of 3.0 and $6.0 \mathrm{~kg} \cdot \mathrm{ha}^{-1}$ for both $\mathrm{Fe}-\mathrm{C}$ sources and at the highest rate for other sources throughout the study. Discoloration at $6.0 \mathrm{~kg} \mathrm{Fe} /$ ha ranged

Table 3. Turfgrass quality ratings in response to application of chelated $\mathrm{Fe}$ sources.

\begin{tabular}{|c|c|c|c|c|c|c|}
\hline \multirow[b]{3}{*}{ Source } & \multicolumn{6}{|c|}{ Quality rating ${ }^{\mathbf{z}}$} \\
\hline & \multicolumn{6}{|c|}{ Days after application, $1986^{y, x}$} \\
\hline & $(2-7)$ & $(30-35)$ & $(2-7)$ & $(30-35)$ & $(2-7)$ & $(37)$ \\
\hline $\mathrm{Fe}-\mathrm{PC}$ & $6.3 \mathrm{a}$ & $6.1 \mathrm{a}$ & $6.1 \mathrm{bc}$ & 6.6 & $7.1 \mathrm{a}$ & $7.4 \mathrm{a}$ \\
\hline $\mathrm{Fe}-\mathrm{C}(\mathrm{EI})$ & $6.1 \mathrm{a}$ & $6.2 \mathrm{a}$ & $6.0 \mathrm{bc}$ & 6.5 & $6.9 \mathrm{a}$ & $7.1 \mathrm{a}$ \\
\hline $\mathrm{Fe}-\mathrm{C}(\mathrm{T})$ & $5.8 \mathrm{ab}$ & $6.1 \mathrm{a}$ & $6.3 \mathrm{~b}$ & 6.4 & $7.1 \mathrm{a}$ & $7.0 \mathrm{a}$ \\
\hline Fe-DTPA & $6.5 \mathrm{a}$ & $6.2 \mathrm{a}$ & $6.8 \mathrm{a}$ & 6.3 & $6.9 \mathrm{a}$ & $7.1 \mathrm{a}$ \\
\hline Nontreated & $5.3 \mathrm{~b}$ & $5.7 \mathrm{~b}$ & $5.6 \mathrm{c}$ & 6.0 & $6.4 \mathrm{~b}$ & $6.4 \mathrm{~b}$ \\
\hline \multirow[t]{3}{*}{ F test } & $* *$ & $* *$ & $* *$ & NS & $* *$ & $* *$ \\
\hline & \multicolumn{6}{|c|}{1987} \\
\hline & (7) & $(31-37)$ & (7) & $(37-42)$ & (7) & $(36)$ \\
\hline Fe-PC & $4.9 \mathrm{~b}$ & $5.9 \mathrm{ab}$ & $5.7 \mathrm{~b}$ & $6.7 \mathrm{a}$ & $6.8 \mathrm{a}$ & $5.9 \mathrm{a}$ \\
\hline $\mathrm{Fe}-\mathrm{C}(\mathrm{EI})$ & $4.9 \mathrm{~b}$ & $5.9 \mathrm{ab}$ & $5.6 \mathrm{~b}$ & $5.7 \mathrm{~cd}$ & $6.8 \mathrm{a}$ & 6.3 \\
\hline $\mathrm{Fe}-\mathrm{C}(\mathrm{T})$ & $5.7 \mathrm{a}$ & $5.8 \mathrm{bc}$ & $5.8 \mathrm{~b}$ & $6.3 \mathrm{ab}$ & $7.1 \mathrm{a}$ & \\
\hline Fe-DTPA & $6.1 \mathrm{a}$ & $6.5 \mathrm{a}$ & $6.6 \mathrm{a}$ & $6.1 \mathrm{bc}$ & $7.0 \mathrm{a}$ & \\
\hline Nontreated & $4.5 \mathrm{~b}$ & $5.3 \mathrm{c}$ & $4.9 \mathrm{c}$ & $5.3 \mathrm{~d}$ & $5.6 \mathrm{~b}$ & $5.1 \mathrm{~b}$ \\
\hline F test & & $* *$ & $* *$ & & $* *$ & \\
\hline
\end{tabular}

${ }^{z} 1$ = brown, low-quality turf; $5=$ acceptable; $9=$ dark green, highquality turf.

yTreatments applied 20 May, 15 July, and 10 Sept. 1986 and 13 May, $8 \mathrm{July}$, and 16 Sept. 1987. Data are the mean of three replicates, averaged across all rates. Numbers in parentheses indicate the days after application included in the mean.

'Mean separation within columns, for a given year, by Duncan's new multiple range test, $P=0.05$.

Ns,**Nonsignificant or significant at $P=0.01$, respectively. from a yellowing (Fe-PC), to brown $[\mathrm{Fe}-\mathrm{C}(\mathrm{EI})]$, to gray coloration of the leaves $[\mathrm{Fe}-\mathrm{C}(\mathrm{T})]$. Turf treated with Fe-DTPA was dark green to black, and was the closest in appearance to a true dark green at the highest rate. Carrow et al. (1988) previously noted less phytotoxicity associated with Fe-DTPA applications to centipedegrass than similar rates of iron sulfate or ferrous ammonium sulfate. They reported $2.0 \mathrm{~kg} \cdot \mathrm{ha}^{-1}$ to be the highest nonphytotoxic Fe rate on centipedegrass, while Fe-DTPA applications as high as $6.0 \mathrm{~kg} \mathrm{Fe} /$ ha were routinely tolerated by Kentucky bluegrass in our study without excessive phytotoxicity.

Turf treated with $\mathrm{Fe}-\mathrm{C}$ sources appeared less dense from late July through September both years. To determine if a decrease in plant density had occurred, two plugs $10 \mathrm{~cm}$ in diameter were removed at random from each plot and the number of tillers per plug counted. The tiller count was similar and the visual perception of thinning appeared to be an artifact of a more noticeably discolored understory. The tendency for Fe application to cause phytotoxicity without decreasing density has been reported previously by Yust et al. (1984) who noted no permanent damage from Fe applications to Kentucky bluegrass at rates as high as $72 \mathrm{~kg} \cdot \mathrm{ha}^{-1}$. In earlier work, Deal and Engle (1965) reported that nonchelated Fe applied at 1.1, 11.2, and 56.0 $\mathrm{kg} \cdot \mathrm{ha}^{-1}$ did not reduce Kentucky bluegrass density.

Nutrient analyses. Tissue Fe content on 31 July 1986 (16 DAT) was increased significantly by all Fe sources relative to nontreated turf (Table 4), with a positive linear response to $\mathrm{Fe}$ rate $(\mathrm{Y}=17.5 \mathrm{X}+57.3)$. Foliar Fe content 14 days after the third application of the 1986 season (24 Sept.) averaged 514 $\mathrm{mg} \cdot \mathrm{kg}^{-1}$ for $\mathrm{Fe}-\mathrm{C}(\mathrm{T})$-treated turf, which was significantly higher than the Fe content resulting from application of other sources. Foliar Fe content in response to Fe fertilization remained high during 1987. Application of Fe-PC and both Fe-C sources resulted in significantly higher foliar Fe content than nontreated turf on all 1987 evaluation dates. Fe-DTPA also resulted in a higher tissue Fe content than found in nontreated turf on two of three evaluation dates during 1987. While all Fe sources elevated Fe content relative to nontreated turf, no source consistently resulted in tissue Fe content higher than other Fe sources. Foliar Fe content during 1987 increased linearly with increasing Fe rate for all sources on 27 May $(\mathrm{Y}=189.5 \mathrm{X}+116.4), 22$ July $(\mathrm{Y}=117.1 \mathrm{X}+121.0)$, and 2 Oct. $(\mathrm{Y}=126.2 \mathrm{X}+$ 154.2).

Application of $\mathrm{Fe}$ chelates containing supplemental P (Fe-

Table 4. Iron concentration of Kentucky bluegrass leaf tissue treated with chelated $\mathrm{Fe}$ sources.

\begin{tabular}{|c|c|c|c|c|c|}
\hline \multirow[b]{3}{*}{ Source } & \multicolumn{5}{|c|}{ Date (days after application) ${ }^{z}$} \\
\hline & \multicolumn{2}{|c|}{1986} & \multicolumn{3}{|c|}{1987} \\
\hline & $\begin{array}{c}31 \text { July } \\
\text { (16) }\end{array}$ & $\begin{array}{l}24 \text { Sept. } \\
\text { (14) }\end{array}$ & $\begin{array}{c}27 \text { May } \\
\text { (14) }\end{array}$ & $\begin{array}{l}22 \text { July } \\
\text { (14) }\end{array}$ & $\begin{array}{c}2 \text { Oct. } \\
(16)\end{array}$ \\
\hline & \multicolumn{5}{|c|}{$m g$ iron $/ \mathrm{kg}$ tissue ${ }^{y, x}$} \\
\hline $\mathrm{Fe}-\mathrm{PC}$ & $81 \mathrm{a}$ & $324 \mathrm{~b}$ & $436 \mathrm{a}$ & $253 b$ & $377 \mathrm{a}$ \\
\hline $\mathrm{Fe}-\mathrm{C}(\mathrm{EI})$ & $81 \mathrm{a}$ & $356 \mathrm{~b}$ & $249 c$ & $254 \mathrm{~b}$ & $379 \mathrm{a}$ \\
\hline $\mathrm{Fe}-\mathrm{C}(\mathrm{T})$ & $73 \mathrm{a}$ & $514 \mathrm{a}$ & $326 \mathrm{bc}$ & $292 a$ & $283 \mathrm{~b}$ \\
\hline Fe-DTPA & $75 \mathrm{a}$ & $263 \mathrm{~b}$ & $340 \mathrm{~b}$ & $232 \mathrm{~b}$ & $167 \mathrm{c}$ \\
\hline Nontreated & $61 \mathrm{~b}$ & $103 \mathrm{~b}$ & $106 \mathrm{~d}$ & $140 \mathrm{c}$ & $133 \mathrm{c}$ \\
\hline F Test & $* *$ & $* *$ & $* *$ & $* *$ & $*$ \\
\hline
\end{tabular}

${ }^{2}$ Treatments applied 20 May, 15 July, 10 Sept. 1986 and 13 May, 8 July, 16 Sept. 1987.

'Data are the mean of three replicates, averaged across all rates.

xMean separation within columns by Duncan's new multiple range test, $P=0.05$.

*,**Significant at $P=0.05$ and 0.01 , respectively. 
$\mathrm{PC}$ ) or $\mathrm{K}[\mathrm{Fe}-\mathrm{PC}$ and $\mathrm{Fe}-\mathrm{C}(\mathrm{T})]$ had no effect on $\mathrm{P}$ or $\mathrm{K}$ tissue content at any time during the study (data not presented). Tissue $\mathrm{P}$ content averaged 3.4 and $3.9 \mathrm{~g} \cdot \mathrm{kg}^{-1}$, while $\mathrm{K}$ content averaged 22.6 and $23.0 \mathrm{~g} \cdot \mathrm{kg}^{-1}$ during 1986 and 1987, respectively. These levels are consistent with results reported by Mehall et al. (1983), who compared 15 Kentucky bluegrass cultivars and found leaf $\mathrm{P}$ and $\mathrm{K}$ to average 2.3 to 3.5 and 21 to $23 \mathrm{~g} \cdot \mathrm{kg}^{-1}$, respectively. Fe-PC and $\mathrm{Fe}-\mathrm{C}(\mathrm{T})$ contained supplemental $\mathrm{P}$ and/ or $\mathrm{K}$ at levels sufficiently low as to have little benefit on this soil with high $\mathrm{P}$ and $\mathrm{K}$ levels.

In conclusion, application of the Fe-PC source resulted in significantly more foliar growth than realized for nontreated turf on seven of 11 sampling dates, while $\mathrm{Fe}-\mathrm{C}$ sources and $\mathrm{Fe}-$ DTPA did not influence growth. Application of Fe resulted in turfgrass quality superior to nontreated turf throughout the study; however, no source consistently provided quality superior to other $\mathrm{Fe}$ sources. Increasing $\mathrm{Fe}$ rate did not result in a corresponding increase in quality, perhaps due to increased phytotoxicity at higher rates. Although $\mathrm{Fe}-\mathrm{C}$ sources produced noticeable phytotoxicity at $6.0 \mathrm{~kg} \mathrm{Fe} / \mathrm{ha}$, repeated application did not reduce turfgrass density. All Fe sources typically resulted in elevated leaf tissue levels of $\mathrm{Fe}$; however, elevated $\mathrm{Fe}$ content was not correlated with increased growth. Supplemental $\mathrm{P}$ and/or $\mathrm{K}$ in Fe sources did not result in increased tissue content of those elements. Turfgrass quality and growth were unaffected by supplemental $\mathrm{P}$ and/or $\mathrm{K}$.

\section{Literature Cited}

Carrow, R. N., B.J. Johnson, and G.W. Landry, Jr. 1988. Centipedegrass response to foliar application of iron and nitrogen. Agron. J. 80:746-750

Deal, E.E. and R.E. Engle. 1965. Iron, manganese, boron, and zinc: effects on growth of 'Merion' Kentucky bluegrass. Agron. J. 57:553555.

Glinski, D., K.J. Karnok, and R.N. Carrow. 1988. Influence of iron on root/shoot growth and water use of bentgrass. Agron. Abstr. p. 151.

Greweling, Thomas. 1976. Chemical analysis of plant tissue. Search Agriculture. vol. 6, no. 8. Cornell Univ. Agr. Expt. Sta., Cornell Univ., Ithaca, N.Y.

Johnson, B. J., R.N. Carrow, and T.R. Murphy. 1990. Foliar-applied iron enhances bermudagrass tolerance to herbicides. J. Amer. Soc. Hort. Sci. 115(3):422-426.

Lunt, H. A., C.L.W. Swanson, and H.G.M. Jacobson. 1950. The Morgan Soil Testing System. Connecticut Agr. Expt. Sta. Bul. 541, New Haven, Conn.

Mehall, B. J., R.J. Hull, and C.R. Skogley. 1983. Cultivar variation in Kentucky bluegrass: P and K nutritional factors. Agron. J. 75:767772 .

Minner, D.D. and J.D. Butler. 1984. Correcting iron deficiency of Kentucky bluegrass. HortScience 19:109-110.

SAS Institute, Inc. 1982. SAS user's guide 1982 ed. SAS Institute, Inc. Cary, N.C.

Schmidt, R.E and V. Snyder. 1984. Effects of N, temperature, and moisture stress on the growth and physiology of creeping bentgrass and response to chelated iron. Agron. J. 76:590-594.

Snyder, V. and R.E. Schmidt. 1974. Nitrogen and iron fertilization of bentgrass, p. 176-185. In: E.C. Roberts (ed.). Proc. 2nd Intl Turfgrass Res. Conf., Blacksburg, Va. 19-21 June 1973. Amer. Soc. Agron. and Crop Sci. Soc. Amer., Madison, Wis.

Turgeon, A.J. 1991. Turfgrass management. Reston Publishing, Reston, Va.

White, R.H. and R.E. Schmidt. 1988. Carbon dioxide exchange of 'Tifgreen' bermudagrass exposed to chilling temperatures as influenced by iron and BA. J. Amer. Soc. Hort. Sci. 113(3):423-427.

Yust, A. K., D.J. Wehner, and T.W. Fermanian. 1984. Foliar application of $\mathrm{N}$ and Fe to Kentucky bluegrass. Agron. J. 76:934-938. 